\title{
Seasonal trends in leaf area of honey mesquite trees: Determination using image analysis
}

\author{
R.J. ANSLEY, D.L. PRICE, S.L. DOWHOWER, AND D.H. CARLSON
}

\begin{abstract}
Authors are post-doctoral research associate, Texas Agricultural Experiment Station, PO 1658, Vernon 76384; project leader, USA CERL, PO 4005, Champaign, Ill. 61826-9005; research associate, Texas Agricultural Experiment Station, PO 1658, Vernon 76384; and research associate, Dept. of Rangeland Ecology and Management Texas A\&M University, College Station 77843.
\end{abstract}

\begin{abstract}
Black-and-white photographs were used to estimate seasonal trends in whole plant leaf area of honey mesquite (Prosopis glandulosa var. glandulosa Torr.) trees occurring on a site with limited subsurface water. Height and canopy width of the trees ranged from 1 to $5 \mathrm{~m}$ and 1 to $7 \mathrm{~m}$, respectively. Images consisted of profile-view angles of trees occurring on flat terrain. Four image variables, height, width, canopy profile perimeter length, and canopy profile area were obtained from the photographs and used to predict leaf area of unharvested trees. Predictive equations were based on adjacent trees which were photographed and harvested for actual leaf arez determination. Canopy profile area was evaluated as the most accurate image variable for predicting leaf area. Whole plant leaf area of unharvested trees varied within and between growing seasons and was dependent on precipitation patterns. During the 1987 growing season, leaf area declined significantly by $14.6 \%$ from $17.1 \mathrm{~m}^{2}$ (1 leaf surface) in May to $14.6 \mathrm{~m}^{2}$ in August, in conjunction with a mid-summer dry period. Leaf area increased in September 1987 in response to late-summer precipitation. Leaf area was less in the spring of 1988 than the spring of 1987 because of lower precipitation during the winter prior to the 1988 than the 1987 growing season. Leaf area did not decline signiffcantly from spring to mid-summer in 1988 as it did the previous year because of atypically high precipitation in July 1988. Leaf area did not increase in September of 1988 as it did in 1987 because of lack of late-season rains in 1988 . These results suggest mesquite on this study site used partial leaf shedding to augment drought resistance.
\end{abstract}

Key Words: biomass, foliage, growth and development, canopy, abscission, phreatophyte

Most studies examining water relations of woody plants growing naturally have concentrated on measurement of physiological responses at the leaf level of resolution (Schulze and Hall 1982, Farquhar and Sharkey 1982). More recent studies have emphasized the need for documenting whole plant responses, including whole plant leaf area (Pook 1985, Caldwell et al. 1986, Nilsen et al. 1987).

Honey mesquite (Prosopis glandulosa var. glandulosa Torr.)is a winter-deciduous tree which occurs throughout arid and semiarid regions of the southwestern United States. Mesquites have been described as drought-avoiding phreatophytes which sustain transpiration during drought and are not drought-deciduous (Thomas and Sosebee 1978, Nilsen et al. 1981, Nilsen et al. 1983, Nilsen et al.

\footnotetext{
Appreciation is expressed to the Wagon Creek Spade Ranch for providing the study site, and the Texas Water Development Board and E. Paul and Helen Buck Waggoner Foundation for providing financial assistance. Assistance in the field was provided by Keith Lawrence, Pete Jacoby, Cecil Meadors, Bryan Sullivan, Tom Wright, Ralph Hicks, Bob Knight, and Rod Heitschmidt. Kathy Young assisted with computer configuration and programming.

This manuscript was published with approval of the director, Texas Agr. Exp. Sta., as TA-25486.

Manuscript accepted 22 August 1991.
}

1986a). However, on certain sites, mesquites do not have access to adequate ground water, and are dependent on shallow lateral roots to supply water (Heitschmidt et al. 1988, Ansley et al. 1990). Little is known regarding seasonal dynamics of whole plant leaf area of these mesquite. We hypothesized that leaf area would be influenced by frequency and abundance of precipitation on these sites.

To avoid labor-intensive sampling, leaf area of large woody plants has been estimated indirectly from measurements of canopy dimensions (height, width, volume, etc.), branch girth, sapwood area, or canopy light interception (Ludwig et al. 1975, Brown 1976, Waring et al. 1977, MacDonald and Forslund 1986, Ganskopp and Miller 1986). While accurate for comparisons within a single point in time, these methods are relatively insensitive for measuring seasonal dynamics (Murray and Jacobson 1982).

Photography at close range offers potential for determining seasonal changes in leaf area. Recent reports have employed photographic techniques to quantify plant structures (Koike 1985, Roebertsen et al, 1988). Liebhold et al. (1988) used digital photography for estimating insect defoliation of black oak (Quercus velutina Lam.).

The objective of this study was to determine seasonal trends in whole plant leaf area (WPLA) of honey mesquite growing on a site which has little available ground water. We also evaluated the utility and accuracy of several image variables for the nondestructive determination of WPLA.

\section{Methods and Materials}

The study was conducted on the Wagon Creek Spade Ranch located $16 \mathrm{~km}$ north of Throckmorton in north central Texas $\left(99^{\circ} 14^{\prime} \mathrm{W}, 33^{\circ} 20^{\prime} \mathrm{N}\right)$. Soils are predominantly deep calcareous clay loams of the Nuvalde series (fine-silty, mixed, thermic Typic Calcuistolls) (Soil Conservation Service 1984). Average annual precipitation is $624 \mathrm{~mm}$ bimodally distributed with peak rainfall in May and September. Number of days with $50 \%$ probability above $0^{\circ} \mathrm{C}$ is 222 with occurrence of last $0^{\circ} \mathrm{C}$ minimum on 1 April and first $0^{\circ}$ minimum on 9 November. Vegetation is a mixture of mid-and shortgrasses with an overstory of few-stemmed mesquite (300-400 trees per ha). Terrain is relatively uniform with slopes $0-2 \%$.

A total of 54 trees of varying sizes were selected for sampling during the 2-year duration of the study. Height, canopy width, and basal stem number of these trees ranged from 1 to $5 \mathrm{~m}, 1$ to 7 , and 1 to 5 , respectively. Forty-two trees were harvested during the study to develop regression equations for predicting WPLA. Twelve trees were left undisturbed and used to estimate seasonal changes in WPLA.

Four 5-cm diameter aluminum access tubes were installed to 3-m depth near each of 3 undisturbed trees. Each tube was located $2 \mathrm{~m}$ from the basal center of each tree and along cardinal directions. Volumetric soil moisture was measured at 20- and 40-cm depths 

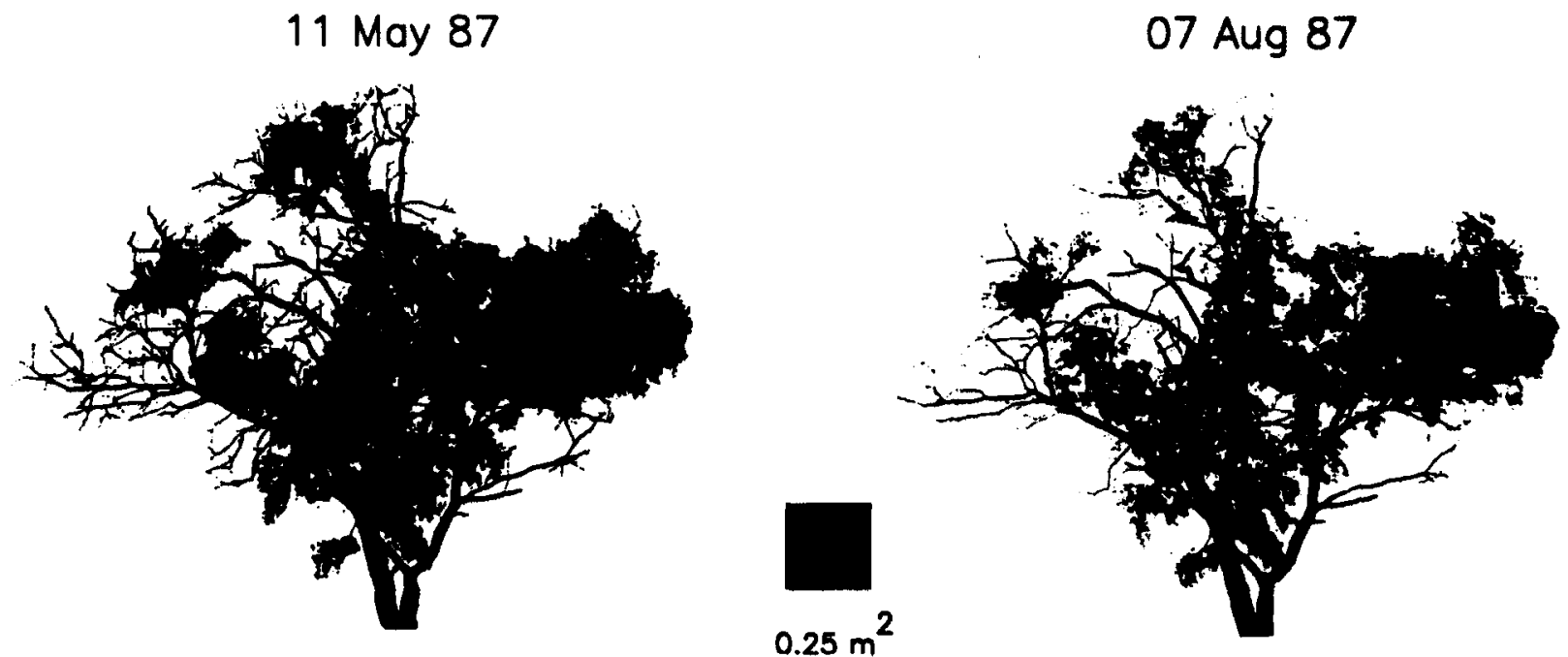

Raference
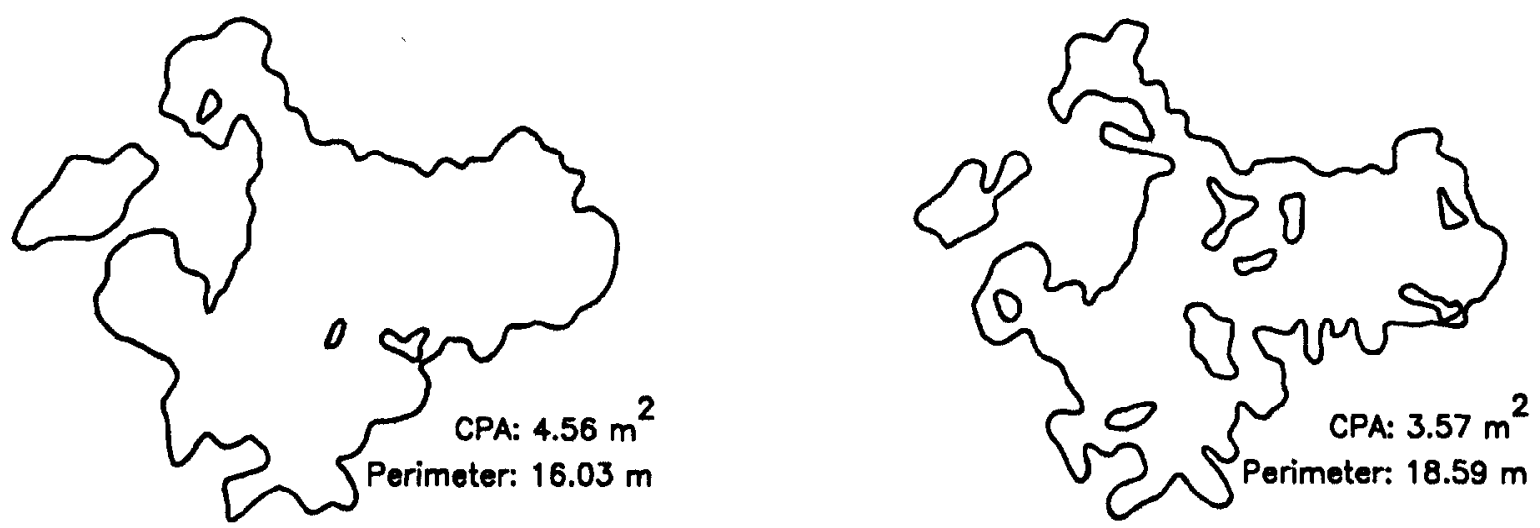

Fig. 1. Profile view of a study tree on 11 May 1987 and 7 August 1987, and canopy profle area (CPA) delineated for each image. CPA and canopy perimeter values are displayed for each image. Reference square $\left(.25 \mathrm{~m}^{2}\right)$ was used to callibrate image variables.

using a neutron attenuation device at 1 -wk intervals. Depths were pooled prior to mean determination for each date. Precipitation was recorded on the site.

A profile-view (i.e., side-view) black-and-white photograph of each tree was obtained on each of 8 sample dates during the growing seasons of 1987 and 1988 using a 300-mm zoom lens from permanently established points located $20 \mathrm{~m}$ from each tree. A $0.25-\mathrm{m}^{2}$ reference square was positioned near each tree during photography for calibration of the images. A truck-mounted, white screen (5-m height $\times 6-\mathrm{m}$ width) was utilized to separate target trees from background vegetation (Ansley et al. 1988). Photographs were enlarged to $20 \times 25 \mathrm{~cm}(8 \times 10$ in.) for image evaluation.

Four image variables, tree height, canopy width, canopy profile perimeter length, and canopy profile area (CPA), were identified on each photograph. CPA was delineated by a hand-drawn line around the outside edge of profiles of tree foliage that occurred on each photograph (Fig. 1). Areas on photographs greater than 0.5 $\mathrm{cm}^{2}$ actual size that did not contain foliage were delineated by hand and subtracted from CPA estimates. Values for CPA were obtained through use of a tablet planimeter (SummaSketch Professional, Summagraphics, Corp., Fairfield, Conn.1) interfaced with an IBM-compatible 80386 computer and tablet software (Sigma-scan; Jandel Scientific, Inc., Corte Madera, Calif. ${ }^{1}$ ). CPA values were recorded as $\mathrm{m}^{2}$ following calibration of the tablet to the known area of $0.25 \mathrm{~m}^{2}$ on each photograph.

\footnotetext{
Mention of product names does not imply endorsement.
}

Within 2 days following each photography sample date, all leaves from 3 or 6 trees were harvested by hand, dried at $60^{\circ}$ for 48 hours, and weighed. Prior to drying and weighing, 4 subsamples of leaves (ranging from 10 to $60 \mathrm{~g}$ fresh weight each) were obtained from the total leaf mass of each harvested tree, and leaf area per subsample was determined with an area meter. Specific leaf area $\left(\mathrm{m}^{2}\right.$ leaf area $/ \mathrm{kg}$ oven dry leaf weight; Coombs et al. 1987) was determined from these subsamples. Total leaf area (1 leaf surface of

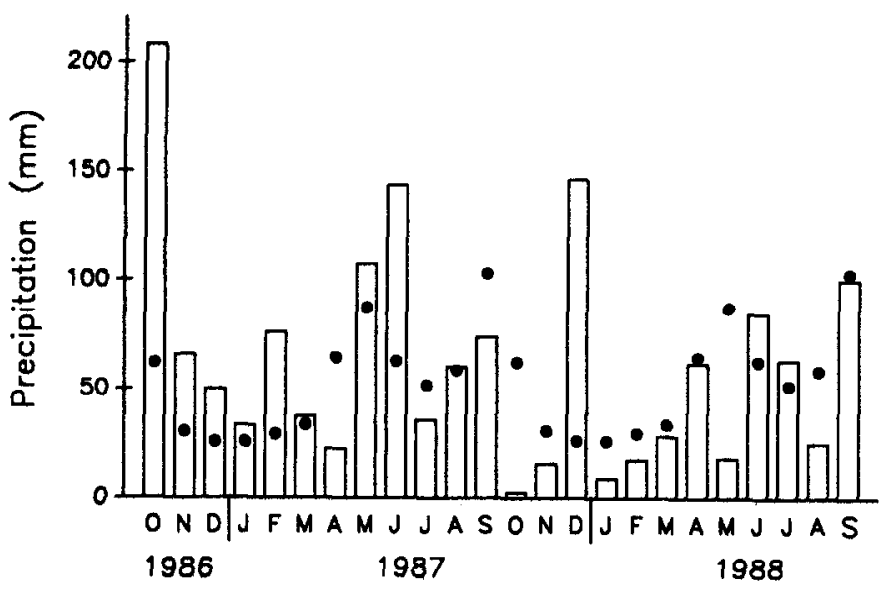

Fig. 2. Monthly precipitation at Spade Wagon Creek Ranch from October 1986 through September 1988. Solid circles indicate the 30-year average for each month. 
each harvested tree (Area-H) was determined by multiplying total oven dry weight by specific leaf area.

Linear regressions were used to predict Area-H from each image variable (height, width, perimeter length, and CPA). Data were pooled across dates to determine which image variable most accurately (i.e., greatest $r^{2}$ ) predicted Area-H throughout the study.

The effect of year on the capacity of the selected image variable to predict WPLA of unharvested trees was then examined by contrasting within year regression models. If significantly different, within years models were used to predict WPLA of unharvested trees.

Prior to analysis, the 12 unharvested trees were stratified into 3 size classes of unequal numbers of trees within each class. A general linear model analysis was performed to assess influence of size class (as blocks) and sample date as main effects on CPA, WPLA, and canopy perimeter length. Means were separated with LSD $(P \leq 0.05)$. All leaf area values reported in this paper refer to the area of 1 surface of each leaf.

\section{Results and Discussion}

\section{Precipitation}

Total annual precipitation was greater in $1987(755 \mathrm{~mm})$ than $1988(470 \mathrm{~mm})$, primarily due to large amounts of rain that fell in June and December of 1987 (Fig. 2). Precipitation during the mesquite growing season (mid-April to mid-October) was slightly above normal in 1987 (432 $\mathrm{mm}$ ) and below normal in 1988 (336 $\mathrm{mm}$ ). Normal precipitation (30-year average) during the mesquite growing season is $426 \mathrm{~mm}$. Distribution of rain during the mesquite growing season was different between years. 1987 was char-
Table 1. Speciflc leaf area during individual sample periods, and when dates were pooled in 1987 and 1988.

\begin{tabular}{lccccc}
\hline \hline \multirow{4}{*}{ Model type } & $\begin{array}{c}\text { Dates } \\
\text { used }\end{array}$ & SLA ${ }^{1}$ & $r^{2}$ & F & $n$ \\
\hline 1987 by date & 11May87 & 9.916 & .99 & $8425^{2}$ & 9 \\
& 11Jun87 & 6.970 & .99 & 2497 & 18 \\
& 10Jul87 & 6.565 & .99 & 5031 & 18 \\
& 07Aug87 & 5.754 & .99 & 4347 & $15^{3}$ \\
& 19Sep87 & 6.116 & .99 & 2861 & 9 \\
1988 by date & 03Jun88 & 6.877 & .99 & 6834 & 18 \\
& 04Aug88 & 5.699 & .99 & 1906 & 21 \\
& 03Oct88 & 4.966 & .99 & 3371 & 18 \\
1987 pooled & 5 dates & 7.057 & .97 & 1950 & 69 \\
1987 pooled & 3 dates ${ }^{4}$ & 6.579 & .99 & 3314 & 42 \\
1988 pooled & 3 dates & 5.944 & .98 & 2801 & 57 \\
\hline
\end{tabular}

'SLA = Specific leaf area $=\left(\mathrm{m}^{2}\right.$ leaf area $/$ oven dry leaf weight $(\mathrm{kg})$. SLA represents “ $\mathrm{a}$ " in each regression, where $\mathrm{y}=\mathrm{ax}$.

${ }^{2} \mathrm{All}$ area:weight regressions were significant at $P<.0001$.

${ }^{3}$ Three samples were destroyed on this date.

4Three dates in 1987 (11 June, 7 Aug., 19 Sept.) were pooled for comparison to 3 pooled dates in 1988 ( 3 June, 4 Aug., 3 Oct.).

acterized by considerable rain in May and June, while 1988 had most rain in June and July. Rainfall was greater during the 3 months (January-March) prior to the $1987(147 \mathrm{~mm})$ than the 1988 (55 mm) growing season.
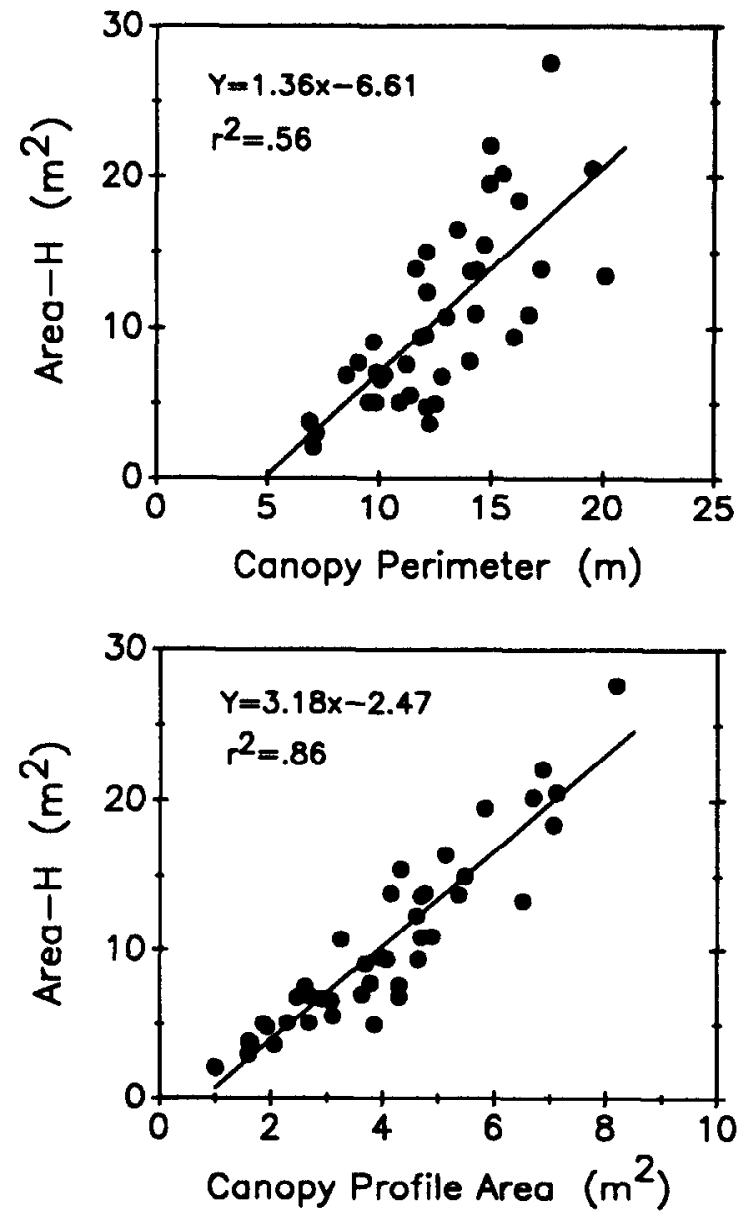

Fig. 3. Relation between 4 image variables (canopy height, width, perimeter length, and profile area) and actual leaf area of each harvested tree (Area-H) for the 42 trees harvested on 8 sample dates. 


\section{Specific Leaf Area}

Mesquite budbreak occurred during the first 2-wks of April of each year and leaves were fully expanded by the first week in May. Specific leaf area declined from 11 May to 7 August 1987, but stabilized from August to 19 September 1987 following significant late August and early September precipitation (Table 1). Specific leaf area declined from 3 June to 3 October 1988. When similar dates were pooled to compare years, specific leaf area was lower in 1988 than 1987.

Declining specific leaf area during each growing season may have been caused by an increase in leaf dry weight due to cell wall thickening in response to drying conditions (Kramer and Kozlowski 1979). This may also explain why specific leaf area was lower in 1988 than 1987, since the 1988 growing season was drier than 1987. Based on these results, specific leaf areas were not pooled across dates to determine total leaf area of harvested trees (Area-H).

\section{Comparison of Image Variables}

When pooled over all sample dates $(n=42)$, canopy profile area (CPA) was more accurate $\left(r^{2}=0.86\right)$ than the other image variables at predicting Area-H (Fig. 3). Canopy height was poorest of the variables at predicting Area-H $\left(r^{2}=0.31\right)$, with canopy profile perimeter length and canopy width intermediate.

Because of its relative ease of measurement, plant height is desirable for predicting WPLA (Murray and Jacobson 1982, Fitzgerald 1983). Height has been used successfully for predicting WPLA of creosotebush (Larrea tridentata), which has a welldefined growth form (Ludwig et al. 1975). Mesquite exhibited a variable growth form, and height was not consistent at predicting Area-H.

Accuracy of CPA may have been confounded to some degree by leaf overlap on the photographs. WPLA may have been underestimated in larger trees, which had greater canopy depth and potentially more leaf overlap than smaller trees (Palmer 1987). Inaccuracies caused by leaf overlap should be minimized in a species such as mesquite, which has a sparsely foliated canopy, in contrast to broadleaf species such as oak (Quercus spp.)

\section{Predicting WPLA of Unharvested Trees}

The relation between CPA and Area-H was best described by an allometric equation: $\mathrm{y}=\mathrm{ax}{ }^{\mathrm{b}}$, where $\mathrm{y}=\mathrm{Area}-\mathrm{H}$ and $\mathrm{x}=\mathrm{CPA}$. When trees from all dates were pooled, this relationship had an $r^{2}=0.87$ $\left(\mathrm{Y}=1.92 \mathrm{x}^{1.18}\right)$.

The relation between CPA and Area-H was significantly different between years (Fig. 4). Foliage was more dense in 1987 than

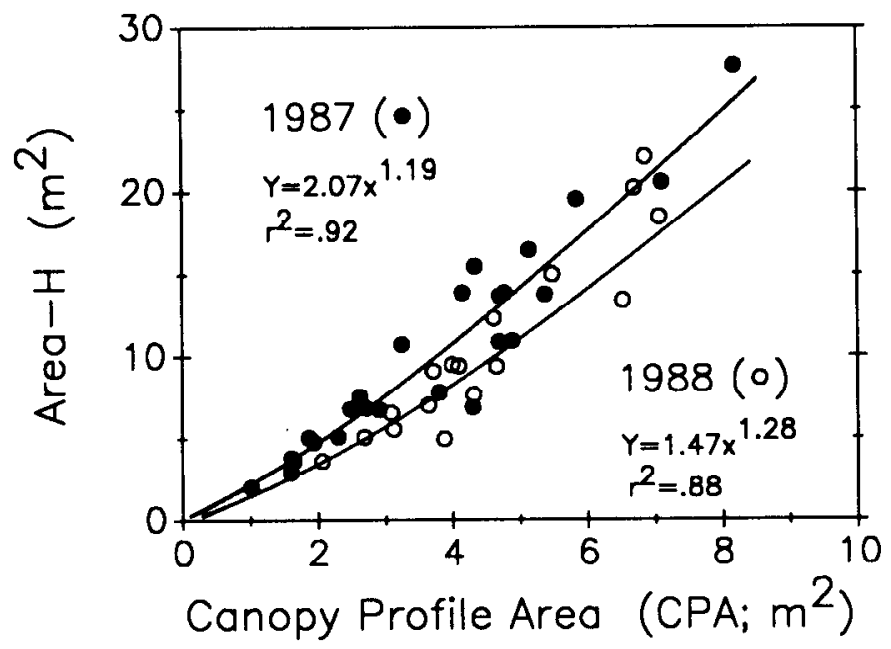

Fig. 4. Relation between CPA and Area-H when pooled among dates within 1987 (filled circles; $n=24$ ) and 1988 (open circles; $n=18$ ).
1988, probably due in part to greater precipitation prior to the 1987 than 1988 growing season. As a result, the curve of the allometric regression between CPA and Area-H was steeper in 1987 than 1988 (i.e., a greater value of " $a$ " in the equation $y=a x^{b}$ ). Because of differences between years, within year allometric equations between CPA and Area-H were used to determine WPLA of unharvested trees during the 1987 and 1988 growing seasons.

\section{Seasonal Trends in WPLA}

Sample date had a significant effect on CPA, WPLA, and canopy perimeter length (Table 2). There was no significant interac-

Table 2. General Linear Models to determine influence of tree size and sample date on CPA, WPLA, and canopy perimeter.

\begin{tabular}{llrrrrl}
\hline \hline Variable & S.V. & df & SS & MS & F & Pr $>$ F \\
\hline CPA & Size & 2 & 251 & 126 & 249 & $.0001^{* * *}$ \\
& Date & 7 & 13 & 2 & 4 & $.0024^{* *}$ \\
& S $\times$ D & 14 & 1 & $<1$ & $<1$ & .9997 NS \\
& Error & 72 & 36 & $<1$ & & \\
& Total & 95 & & & & \\
WPLA & Size & 2 & 2740 & 1370 & 280 & $.0001^{* * *}$ \\
& Date & 7 & 137 & 20 & 4 & $.0010^{* * *}$ \\
& S $\times D$ & 14 & 10 & $<1$ & $<1$ & .9999 NS \\
& Error & 72 & 353 & & & \\
& Total & 95 & & & & \\
Perimeter & Size & 2 & 901 & 450 & 77 & $.0001 * * *$ \\
& Date & 7 & 97 & 14 & 2 & $.0313 *$ \\
& S $\times$ D & 14 & 76 & 5 & 1 & 5349 NS \\
& Error & 72 & 421 & 6 & & \\
& Total & 95 & & & & \\
\hline
\end{tabular}

tion between tree size class and sample date for any variable.

WPLA of unharvested trees declined significantly by $14.6 \%$ during the 1987 growing season from peak levels on 11 May (17.1 $\mathrm{m}^{2}$ ) to lowest levels $\left(14.6 \mathrm{~m}^{2}\right)$ on 7 August (Fig. 5). Each of the 12 trees in the study displayed a mid-summer decline in WPLA. Maximum decline for any individual tree was $28.2 \%$. Mean WPLA increased from August to September 1987, although this change was not statistically significant. WPLA of 10 of the 12 trees increased from August to September.

Seasonal trends in WPLA were variable between years. WPLA was less in June 1988 than in June 1987 and did not decline significantly from June to August in 1988 as it did in 1987. Later in the growing season, WPLA decreased from August to early October 1988, while it increased during the same interval in 1987.

Differences in seasonal trends of WPLA between years were related to differential precipitation patterns between years. Greater WPLA in June 1987 than in June 1988 may be attributed to greater precipitation prior to the 1987 growing season than that of 1988 (Fig. 2), or may have been caused by over $100 \mathrm{~mm}$ of rain that occurred over 10 consecutive days in May 1987 in contrast to the relatively dry May in 1988 (Fig. 5). A soaking rain occurred during a 2-wk interval in late June and early July 1988 in which $85 \mathrm{~mm}$ fell. This type of storm was atypical for July in this region and did not occur in 1987. It may explain why the decline in WPLA from June to August was less in 1988 than in 1987.

Mesquite will grow a new cohort of leaves in late summer if conditions are favorable (Nilsen et al. 1987). A major rain in late August $1987(55 \mathrm{~mm})$ may have stimulated new leaf production and an increase in WPLA from 7 August to 19 September. No rain greater than $18 \mathrm{~mm}$ occurred during August or early September 1988, and, consequently, WPLA declined from 4 August to 3 October. Precipitation in late September 1988 apparently occurred too late to affect WPLA by the 3 October sample date. 


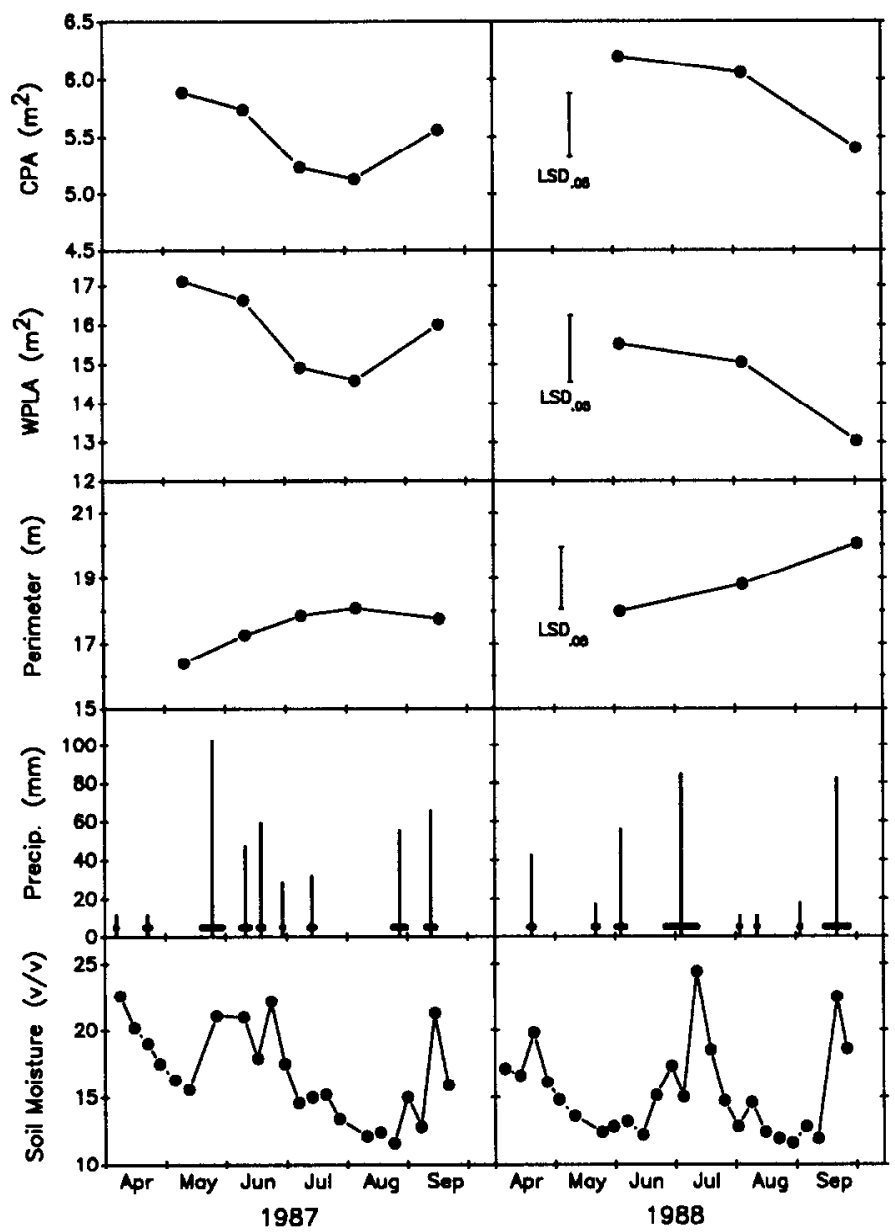

Fig. 5. Mean canopy profile area (CPA), whole plant leaf area (WPLA; 1 leaf surface) and canopy perimeter length of the 12 unharvested trees, individual precipitation events, and volumetric soil moisture at Spade Wagon Creek Ranch during the 1987 (left column) and 1988 (right column) mesquite growing seasons. LSD bars are for 2 -way comparisons among all 8 sample dates. For precipitation data: vertical bars are amount and horizontal bars are duration of each event.

Differences in WPLA between years were consistent with yearly trends in surface soil moisture. During 1987, the decline in soil moisture from mid-June to mid-August, and subsequent increase in late August paralleled the seasonal decline and increase in WPLA (Fig. 5). A seasonal peak in soil moisture during mid-July 1988 may explain why WPLA decreased only slightly from 3 June to 4 August.

Canopy perimeter length followed a seasonal pattern which was the inverse of CPA and WPLA and tended to increase as each growing season progressed (Fig. 5). As leaf area declined, the perimeter of the canopy profile became more irregular and this increased perimeter length. Greater perimeter length in 1988 than 1987 was probably the result of new stem and shoot elongation which occurred in May 1988 as well as drier growing conditions in 1988

\section{Summary}

While the decline in leaf area during mid-summer 1987 was statistically significant, the question remains as to whether this represents a significant biological process. Nilsen et al. (1983) and Nilsen et al. (1986a) indicated that relative leaf area (percent of maximum) of phreatophytic mesquite ( $P$. glandulosa var. torreyana) in the Sonoran desert of southern California remained nearly unchanged from May to November. Maintenance of maximum leaf area during the hottest and driest part of the year was attributed to taproot access to deep water. To confirm this, Nilsen et al. (1986b) demonstrated that when water availability was reduced to normally phreatophytic taproots of mesquite, total leaf area declined. Our results indicated a sensitivity of mesquite to summer dry periods, suggesting the trees on our site were less phreatophytic than those described in the Sonoran desert.

Reduction in mesquite leaf area did not approach levels normally associated with drought-deciduous species (Kozlowski 1973). Pook (1985), for example, found that leaf area of Eucalyptus maculata Hook declined by an average of $80 \%$ during drought in Australia. In the present study, mesquite leaf shedding appeared to be a site-specific adaptation of semi- or nonphreatophytic individuals to augment other drought resistance strategies. These strategies have been previously identified and include increased use of shallow lateral roots (Heitschmidt et al. 1988, Ansley et al. 1990), and increased stomatal sensitivity to soil and atmospheric drought (Ansley et al. 1992).

Insect predation can not be ruled out as a causative factor in diminution of mesquite leaf area. Mesquite is generally susceptible to grasshoppers (Orthoptera: Acrididae) and possibly walking sticks (Diapheromera velii Walsh) (Hewitt et al. 1974). However, we did not notice excessive populations of either of these types during either year of the study. The mesquite twig girdler (Oncideres rhodosticta Bates and $O$. cingulata Say) can reduce leaf area by destruction of phloem in small branches (Rogers 1977). This damage does not occur until late September and October and was not observed to any extent in either year.

\section{Literature Cited}

Ansley, R.J., D.L. Price, B.K. Lawrence, and P.W. Jacoby. 1988. A truck-mounted mobile screen for photodigital estimation of whole plant leaf area. J. Range Manage. 41:355-358.

Ansley, R.J., P.W. Jacoby, and G.J. Cuomo. 1990. Water relations of Prosopis glandulosa Torr. following severing of lateral roots: Influence of location and amount of subsurface water. J. Range Manage. 43:436-442.

Ansley, R.J., P.W. Jacoby, C.H. Meadors, and B.K. Lawrence. 1992. Soil and leaf water relations of differentially moisture-stressed honey mesquite (Prosopis glandulosa Torr). J. Arid Environ. 22:147-159.

Brown, J.K. 1976. Estimating shrub biomass from basal stem diameters. Can. J. Forest. Res. 6:153-158.

Caldwell, M.M., H.P. Meister, J.D. Tenhunen, and O.L. Lange. 1986. Canopy structure, light microenvironment and leaf gas exchange of Quercus coccifera I. in a Portugese macchia: measurements in different canopy layers and simulation with a canopy model. Trees 1:25-41.

Coombs, J., D.O. Hall, S.P. Long, and J.M.O. Scurlock. 1987. Techniques in bioproductivity and photosynthesis. 2nd Edit. Pergamon Press, N.Y.

Farquhar, G.D., and T.D. Sharkey. 1982. Stomatal conductance and photosynthesis. Annu. Rev. Plant Physiol. 33:317-345.

Fitzgerald, R.D. 1983. An indirect method to estimate the aerial biomass of small single-stemmed woody plants. J. Range Manage. 36:757-759.

Ganskopp, D., and R. Miller. 1986. Estimating leaf area of big sagebrush from measurement of sapwood. J. Range Manage. 39:338-340.

Heitschmidt, R.K., R.J. Ansley, S.L. Dowhower, P.W. Jacoby, and D.L. Price. 1988. Some observations from the excavation of honey mesquite root systems. J. Range Manage. 41:227-231.

Hewitt, G.B., E.W. Huddleston, R.J. Lavigne, D.N. Ueckert, and J.G. Watts. 1974. Rangeland entomology. Range Science Ser. No. 2, Soc. Range Manage., Denver, Colo.

Koike, F. 1985. Reconstruction of two-dimensional tree and forest and canopy profiles using photographs. J. Appl. Ecol. 22:921-929.

Kozlowski, T.T. 1973. Extent and significance of shedding of plant parts. p. 1-37. In: T. T. Kozlowski (ed.). Shedding of Plant Parts. Acad. Press, N.Y.

Kramer, P.J., and T.T. Kozlowski. 1979. Physiology of woody plants. Academic Press, N.Y. 
Liebhold, A.M., J.S. Elkinton, D.R. Miller, and Y.S. Wang. 1988. Estimating oak leaf area index and Gypsy moth, Lymantria dispar (L.) (Lepidoptera:Lymlantriidae), defoliation using canopy photographs. Environ. Entomol. 17:560-566.

Ludwig, J.A., J.F. Reynolds, and P.D. Whitson. 1975. Size-biomass relationships of several Chihuahuan desert shrubs. Amer. Midl. Natur. 94:451-461.

MacDonald, G.B., and R.R. Forslund. 1986. Application of a geometric volume equation to species with different bole forms. Can. J. Forest Res. 16:311-314.

Murray, R.B., and M.Q. Jacobson. 1982. An evaluation of dimension analysis for predicting shrub biomass. J. Range Manage. 35:451-454.

Nilsen, E.T., P.W. Rundel, and M.R. Sharifi. 1981. Summer water relations of the desert phreatophyte Prosopis glandulosa in the Sunoran desert of southern California. Oecologia 50:271-276.

Nilsen, E.T., M.R. Sharifi, P.W. Rundel, W.M. Jarrell, and R.A. Virginia. 1983. Diurnal and seasonal water relations of the desert phreatophyte Prosopis glandulosa (honey mesquite) in the Sonoran desert of California. Ecology 64:1381-1393.

Nilsen, E.T., M.R. Sharifi, P.W. Rundel, and R.A. Virginia. 1986a. Influences of microclimatic conditions and water relations on seasonal dimorphism of Prosopis glandulosa var torreyana in the Sonoran desert, California. Oecologia 69:95-100.

Nilsen, E.T., R.A. Virginia, and W.M. Jarrell. 1986b. Water relations and growth characteristics of Prosopis glandulosa var. torreyana in a simulated phreatophytic environment. Amer. J. Bot. 73:427-433.
Nilsen, E.T., M.R. Sharifi, and P.W. Rundel. 1987. Leaf dynamics in an evergreen and a deciduous species with even aged leaf cohorts, from different environments. Amer. Midl. Natur. 118:46-55.

Palmer, J.W. 1987. The measurement of leaf area in apple trees. J. Hort. Sci. 62:5-10.

Pook, E.W. 1985. Canopy dynamics of Eucalyprus maculata Hook. III. Effects of drought. Aust. J. Bot. 33:65-79.

Roebertsen, G., G.W. Heil, and R. Bobbink. 1988. Digital picture processing: a new method to analyze vegetation structure. Acta Bot. Neerl. 37:187-192.

Rogers, C.E. 1977. Bionomics of Oncideres cingulata (Coleoptera:Cerambycidae) on mesquite. J. Kansas Entomol. Soc. 50:222-228.

Schulze, E.-D., and A.E. Hall. 1982. Stomatal responses, water loss and $\mathrm{CO}_{2}$ assimilation rates of plants in contrasting environments. Chap. $7 \mathrm{p}$. 181-224. In: O.L. Lange et al. (eds.) Physiol. Plant Ecol. II. Vol. 12B. Encyclop. Plant Physiol. Springer Verlag, Berlin.

Soil Conservation Service. 1984. Field office technical guide. USDA, Abilene, Tex.

Thomas, G.W., and R.E. Sosebee. 1978. Water relations of honey mesquite-a facultative phreatophyte. Proc. Ist Int. Rangeland Congr., Denver, Colo. p. 414 418.

Waring, R.H., H.L. Gholz, C.C. Grier, and M.P. Plummer. 1977. Evaluating stem conducting tissue as an estimator of leaf area in 4 woody angiosperms. Can. J. Bot. 55:1474-1477. 